\title{
PARITAS, USIA, DAN JARAK KELAHIRAN TERHADAP KEJADIAN ANEMIA PADA IBU HAMIL
}

\author{
Amrina Octaviana ${ }^{1 *}$, Nelly Indrasari ${ }^{2}$ \\ 1,2 Jurusan Kebidanan Politeknik Kesehatan Tanjungkarang, Lampung, Indonesia \\ *Korespondensi email : amrinaoctaviana@poltekkes-tjk.ac.id
}

\begin{abstract}
PARITY, AGE, AND DISTANCE OF BIRTH TO THE EVENT OF ANEMIA FOR PREGNANT WOMEN
\end{abstract}

Background: Anemia in pregnant women is one of the health problems in Indonesia that is often experienced by women of childbearing age, especially pregnant women. Pregnant women who suffer from anemia have a risk of maternal death during the antenatal, perinatal, postnatal period and are at risk of giving birth to babies with low birth weight (LBW). In Indonesia, Pregnant women who experienced anemia in 2013 were $37.1 \%$ and increased in 2018 by $48.9 \%$.

Purpose: To determine the determinants of pregnant women with anemia at Puskesmas Karta Raharja \& Marga Kencana, Tulang Bawang Barat Regency in 2020 seen from internal and External factors from Pregnant Women with Anemia.

Methods: This type of correlation analytic research uses a cross-sectional approach. The research sample was pregnant women in the area of Puskesmas Karta Raharja \& Marga Kencana. Based of a minimum sample of 100 respondents, Examination and sampling were carried out according to the form the inclusion and exclusion criteria of the study. The research analysis used a logistic test using a computer.

Results: This research showed that pregnant women who had anemia were $26 \%$, the most dominant internal factors with the incidence of anemia in pregnant women were maternal parity ( $p$-value 0.017 ), maternal age ( $p$-value 0.017), and birth spacing ( $p$-value 0.000. ). As for external factors, there was no significant relationship with the incidence of anemia in pregnant women.

Conclusion: This proves that parity, maternal age, and birth spacing affect the incidence of anemia in pregnant women at Puskesmas Karta Raharja \& Marga Kencana, Tulang Bawang Barat district in 2020.

Suggestion: The results of this study can be improved to provide more relevant information and learning references for the determinants of Anemia as an effort to prevent and support the achievement of Maternal Health in Tulang Bawang Barat.

Keywords: pregnant women, anemia

\section{ABSTRAK}

Latar Belakang: Anemia pada ibu hamil merupakan salah satu masalah kesehatan di Indonesia yang sering dialami wanita usia subur terutama oleh ibu hamil. Ibu hamil yang menderita anemia mempunyai resiko kematian ibu pada masa antenatal, perinatal, masa postnatal serta beresiko melahirkan bayi dengan berat badan lahir rendah (BBLR). Ibu hamil yang mengalami anemia di Indonesia tahun 2013 sebanyak $37,1 \%$ dan meningkat ditahun 2018 sebanyak $48,9 \%$.

Tujuan: Untuk mengetahui determinan ibu hamil Anemia di Puskesmas Karta Raharja \& Marga Kencana Kabupaten Tulang Bawang Barat tahun 2020 dilihat dari faktor internal dan eksternal lbu Hamil dengan Anemia. Metode: Jenis penelitian analitik korelasi menggunakan pendekatan Crossectional. Sampel penelitian adalah ibu hamil di wilayah Puskesmas Karta Raharja \& Puskesmas Marga Kencana, dengan perhitungan sampel minimal 100 responden, dilakukan pemeriksaan dan penjaringan sampel sesuai dengan form dan kriteria inklusi dan ekslusi peneltian. Analisis penelitian dengan uji logistik menggunakan komputer.

Hasil: Hasil penelitian menunjukkan ibu hamil yang mengalami anemia sebanyak $26 \%$, Faktor Internal yang paling dominan dengan kejadian Anemia pada ibu hamil adalah paritas ibu ( $p$-value 0.017), umur ibu ( $p$ value 0.017), dan jarak kelahiran (p-value 0.000). Sedangkan untuk faktor eksternal didapatkan tidak ada hubungan signifikan dengan kejadian anemia pada ibu hamil.

Kesimpulan: Pada peneltian didaptkan Faktor Internal yaitu paritas dan umur ibu, serta jarak kelahiran mempengaruhi kejadian Anemia pada lbu Hamil di Puskesmas Karta Raharja \& Marga Kencana Kabupaten Tulang Bawang Barat tahun 2020. 


\section{JKM (Jurnal Kebidanan Malahayati),Vol 7,No.3.Juli 2021, \\ ISSN (Print) 2476-8944 ISSN (Online) 2579-762X, Hal 510-517}

Saran: Hasil penelitian ini dapat terus ditingkatkan untuk memberikan informasi dan referensi pembelajaran yang lebih relevan mengenai determinan Anemia sebagai salah satu upaya pencegahan dan mendukung tercapainya Kesehatan Ibu di Tulang Bawang Barat.

Kata Kunci : Ibu hamil, Anemia

\section{PENDAHULUAN}

Masa kehamilan merupakan masa yang sangat menetukan kualitas sumber daya manusia masa depan, karena tumbuh kembang anak sangat ditentukan kondisinya dimasa janin dalam kandungan. Salah satu faktor yang mempengaruhi kesehatan ibu adalah keadaan gizi ibu (Umu Hani, 2018). Anemia pada ibu hamil merupakan salah satu masalah kesehatan di Indonesia yang sering dialami wanita usia subur terutama oleh ibu hamil. Ibu hamil yang mengalami anemia apabila kehamilan trimester pertama dan trimester ketiga kurang dari $11 \mathrm{gram} \%$, atau sebesar $10,5 \mathrm{gram} \%$ pada kehamilan trimester kedua (Saifuddin AB, 2011).

Prevalensi anemia pada wanita hamil di Indonesia berkisar $20-80 \%$, tetapi pada umumnya banyak penelitian yang menunjukkan anemia pada wanita hamil yang lebih besar dari $50 \%$. Di wilayah Indonesia bagian barat daerah tergolong tinggi, anemia di Aceh sebanyak 56,6\%, Sumatera utara $77,9 \%$, Sumatera Barat 8,9\%, Riau 65,6\%, Jambi $74,2 \%$, Sumatera Selatan $58,3 \%$, Lampung $60,7 \%$ (Sjahriani \& Faridah, 2019). Sebagian besar anemia di Indonesia selama ini dinyatakan sebagai akibat kekurangan besi $(\mathrm{Fe})$ yang diperlukan untuk pembentukan hemoglobin, sehingga Pemerintah Indonesia mengatasinya dengan mengadakan pemberian suplemen besi untuk ibu hamil, namun hasilnya belum memuaskan. Penduduk Indonesia pada umumnya mengkonsumsi Fe dari sumber nabati yang memiliki daya serap rendah dibanding sumber hewani. Kebutuhan Fe pada janin akan meningkat hingga pada trimester akhir sehingga diperlukan suplemen Fe.(Sulistioningsih, 2018).

Anemia dalam kehamilan dapat disebabkan oleh beberapa faktor diantaranya adalah kepatuhan konsumsi tablet $\mathrm{Fe}$, paritas, umur ibu, frekuensi antenatal care (ANC), sosial ekonomi, pengetahuan, pendidikan, budaya, dukungan suami, dan infeksi (Ariyani, 2016). Berdasarkan penelitian terdahulu menunjukkan ada hubungan antara jarak kehamilan dengan kejadian anemia. Jarak kehamilan resiko rendah yaitu jarak ibu melahirkan bayi $\geq 2$ tahun sampai 10 tahun sebagian besar mengalami anemia ringan yaitu kadar hemoglobin $(\mathrm{Hb})$ ibu hamil $\geq 8 \mathrm{~g} \%-<11 \mathrm{~g} \%$. Sedangkan pada ibu yang memiliki jarak kehamilan beresiko tinggi yaitu jarak ibu melahirkan bayi $<2$ tahun atau $\geq 10$ tahun sebagian besar mengalami anemia berat yaitu kadar hemoglobin $(\mathrm{Hb})$ ibu hamil $<8 \mathrm{~g} \%$ (Nurhidayah, 2013).

Di Indonesia diperkirakan setiap harinya terjadi 41 kasus anemia, dan 20 perempuan meninggal dunia karena kondisi tersebut. Tingginya angka ini disebabkan oleh rendah pengetahuan dan kesadaran akan bahaya anemia dalam kehamilan cenderung muncul pada kehamilan Trimester 1 dan III (Yuliatin, 2018). Banyak wanita mengalami kekurangan zat besi pada trimester II dan III, akibat kebutuhan zat besi yang tinggi ditambah dengan peningkatan cairan plasma darah yang menyebabkan hemodilusi tetapi tidak dibarengi dengan pemasukkan zat besi yang adekuat, maka dapat menyebabkan anemia dalam kehamilan (Proverawati A, 2011). Temuan serupa juga ditemukan pada penelitian di Ethiophia, yang menemukan, bahwa anemia lebih mudah terjadi pada trimester III akibat penurunan cadangan zat besi dibandingkan trimester II dan trimester I dan sebagiaan besar responden tidak patuh dalam mengkonsumsi suplemen zat besi (Gedefaw $L$, et al, 2015).

Angka kematian ibu (AKI) mencerminkan risiko yang dihadapi Anemia pada kehamilan dan melahirkan yang dipengaruhi oleh status gizi ibu, keadaan sosial ekonomi, keadaan kesehatan yang kurang baik menjelang kehamilan, kejadian berbagai komplikasi pada kehamilan dan kelahiran, tersedianya dan penggunaan fasilitas pelayanan kesehatan termasuk pelayanan prenatal dan obstetri (Amalia, 2018). Ibu hamil yang menderita anemia mempunyai resiko kematian pada masa antenatal, perinatal, dan postnatal serta beresiko melahirkan bayi dengan berat badan lahir rendah (BBLR). Pada keadaan ini banyak ibu yang meninggal karena perdarahan, infeksi sehingga akan meningkatkan angka kematian ibu dan anak (Cakrawati, 2012).

Anemia merupakan gejala dari kondisi yang mendasari, seperti kehilangan komponen darah, elemen tidak adekuat atau kurangnya nutrisi yang dibutuhkan untuk pembentukan sel darah merah yang mengakibatkan penurunan kapasitas pengangkut oksigen darah (Adisasmito, 2018). Bila $\mathrm{Hb}$ ibu sebelum hamil sekitar $11 \%$, dengan 
terjadinya hemodilusi akan mengakibatkan anemia hamil fisiologis, dan $\mathrm{Hb}$ ibu beresiko menurun menjadi $9,5-10 \%$. Setelah persalinan dengan lahirnya plasenta dan perdarahan ibu akan beresiko mengalami kehilangan zat besi sekitar $900 \mathrm{mg}$. Saat laktasi, ibu masih memerlukan kesehatan jasmani yang optimal untuk dapat menyiapkan ASI untuk perkembangan da pertumbuhan bayi. Dalam keadaan anemia, laktasi tidak mungkin dapat dilaksanakan dengan baik (Manuaba, 2010).

Hasil Riset Kesehatan Dasar (Riskesdas) 2018 yang dilakukan Kementerian Kesehatan memperlihatkan bahwa sebanyak 49,5\% perempuan hamil mengkonsumsi protein dibawah $80 \%$ dari yang dibutuhkannya semasa kehamilan dan $44,8 \%$ perempuan hamil itu juga kurang mendapatkan asupan energi secara total yakni masih dibawah $70 \%$ dari yang dibutuhkan (Dekes $\mathrm{RI}, 2018$ ). Proporsi lbu hamil yang mengalami anemia tahun 2013 sebanyak $37,1 \%$ dan meningkat pada tahun 2018 sebanyak 48,9\%. Di satu sisi masih ada ibu hamil yang tidak mendapat Tablet Tambah Darah (TTD) 26,8\%. Sedangkan, Ibu hamil yang mendapatkan TTD sebanyak $73,2 \%, 24 \%$ diantaranya mendapat $\geq 90$ tablet tetapi yang di minum $<90$ tablet, dan $61,9 \%$ bumil yang mendapat $>90$ tablet, hanya 38,1\% TTD di minum oleh ibu hamil, serta masih ada ibu hamil sebanyak $76 \%$ yang tidak mendapat TTD sesuai anjuran $\quad<90$ tablet) (Litbangkes, 2018).

\section{METODOLOGI PENELITIAN}

Desain Penelitian adalah Analitik korelasi yang menggunakan pendekatan Crossectional. Lokasi penelitian ini dilakukan di wilayah Kabupaten
Tulang Bawang Barat yang dilaksanakan dari bulan Juni - Desember 2020.

Variabel penelitian terdiri dari Varibael Dependent adalah Ibu hamil dengan anemia dan Variabel Independent adalah Faktor Internal dan Eksternal Ibu. Faktor Internal terdiri dari : Paritas, Umur ibu, Jarak kelahiran, Status gizi, Infeksi dan penyakit, Usia kehamilan. Faktor Eksternal : Pendidikan, Pendapatan keluarga, Pekerjaan, Kepatuhan konsumsi PMT dan tablet FE.

Populasi dalam penelitian ini adalah seluruh ibu hamil di wilayah Puskesmas Karta Raharja \& Puskesmas Marga Kencana Kabupaten Tulang Bawang Barat tahun 2020. Sampel penelitian ini adalah semua ibu hamil yang telah dilakukan pemeriksaan dan dilakukan penjaringan sampel sesuai dengan form yang sudah disediakan. Berdasarkan perhitungan sampel minimal sejumlah 100 respoden, dengan kriteria Inklusi sampel yaitu Ibu hamil yang memenuhi kriteria sampling, Berumur 20 - 45 tahun, Ibu hamil yang bersedia jadi responden.

Peneliti bersama enumerator akan mengidentifikasi responden yang akan diteliti sesuai dengan kriteria inklusi dengan dilakukan wawancara dan pemeriksaan, selanjutnya peneliti akan menjelaskan proses penelitian dan mengajukan informed consent. Sebelum ditentukan menjadi responden, dilakukan pengukuran LILA, TB, BB, dan kadar Hemoglobin. Setelah itu dilakukan wawancara untuk mengumpulkan data yang dibutuhkan. Analisis deskriptif dilakukan untuk mengetahui gambaran responden secara umum, dilanjutkan dengan uji logistik menggunakan komputer.

\section{HASIL DAN PEMBAHASAN}

Analisis Univariat

Tabel 1.

Distribusi Frekuensi Karakteristik Responden Ibu Hamil di Puskesmas Karta Raharja dan Puskesmas Marga Kencana Kab. Tulang Bawang Barat Tahun 2020

\begin{tabular}{lccc}
\hline \multicolumn{1}{c}{ Variabel } & Sub-Variabel & Frekuensi & Prosentase (\%) \\
\hline Pendidikan & Rendah & 52 & 52 \\
& Tinggi & 48 & 48 \\
Pendapatan Keluarga & Rendah & 77 & 77 \\
& Tinggi & 23 & 23 \\
Pekerjaan & Tidak Bekerja & 86 & 86 \\
Kepatuhan konsumsi PMT & Bekerja & 14 & 14 \\
dan Tablet Fe & Tidak Patuh & - & - \\
Paritas & Patuh & 100 & 100 \\
\multirow{2}{*}{ Umur } & $>4$ anak & 20 & 20 \\
& $<4$ anak & 80 & 80 \\
& $<20$ atau $>35$ th & 26 & 26 \\
& $20-35$ th & 74 & 74
\end{tabular}


JKM (Jurnal Kebidanan Malahayati),Vol 7,No.3.Juli 2021,

ISSN (Print) 2476-8944 ISSN (Online) 2579-762X, Hal 510-517

Jarak Kelahiran

Status Gizi

Infeksi dan Penyakit

Usia Kehamilan
$<2$ th

$>2$ th

Gizi Kurang

Gizi Baik

Ada

Tidak

TM I dan TM III

TM II
7

93

26

74

100

44

56

\section{7 \\ 93 \\ 26 \\ 74 \\ 100 \\ 44 \\ 56}

Berdasarkan Tabel 1 dapat dilihat bahwa responden dengan pendidikan rendah sebanyak $52 \%$, Responden dengan pendapatan keluarga rendah sebanyak $77 \%$, dan $86 \%$ respondan adalah ibu rumah tangga. Semua ibu hamil patuh konsumsi PMT dan tablet Fe serta tidak memiliki infeksi atau penyakit lainnya. Ibu yang memiliki paritas $>4$ anak sebanyak $20 \%$. Sedangkan ibu hamil dengan usia $<20$ atau $>35$ tahun dengan status gizi kurang sebanyak $26 \%$. Mayoritas ibu hamil memiliki jarak kelahiran >2 tahun (93\%). Dilihat dari usia kehamilan, responden didominasi oleh Ibu hamil trimester II sebanyak 56\%, kemudian lbu hamil trimester I dan III sebanyak $44 \%$.

Tabel 2.

Distribusi Frekuensi lbu Hamil dengan Anemia di Puskesmas Karta Raharja dan Puskesmas Marga Kencana Kab. Tulang Bawang Barat Tahun 2020

\begin{tabular}{lc}
\hline \multicolumn{1}{c}{ Variabel } & Jumlah (\%) \\
\hline Ibu hamil Anemia & 26 \\
Ibu Hamil Tidak Anemia & 74 \\
\hline
\end{tabular}

\section{Total} 100

Pada Tabel diatas kategori tertinggi pada lbu hamil yang tidak anemia yaitu sebesar $74 \%$ dan ibu hamil yang mengalami Anemia sebanyak $26 \%$ dari total responden yang ada di Puskesmas Kartaraharja dan Marga Kencana.

\section{Analisis Bivariat}

Berdasarkan Tabel 3 di atas, variabel yang paling berhubungan dengan kejadian Anemia yaitu ibu hamil dengan Paritas diatas 4 anak beresiko 5 kali mengalami Anemia bila dibandingkan dengan ibu yang melahirkan anak kurang dari 4 ( $\mathrm{Cl}$ 95\% $=4.995$ ), kemudian ibu hamil dengan umur $<20$ atau $>35$ tahun beresiko 4 kali mengalami Anemia jika dibandingkan dengan ibu hamil usia 20-35 tahun (Cl 95\%=3.918), dan ibu hamil dengan jarak kelahiran $<2$ tahun lebih beresiko 2 kali mengalami Anemia jika dibandingkan dengan ibu hamil yang jarak kelahiran anaknya $>2$ tahun $(\mathrm{Cl} 95 \%=1.579)$. Untuk variabel yang tidak berhubungan adalah status gizi, infeksi dan penyakit, serta usia kehamilan.

Tabel 3.

Faktor Internal Terhadap Kejadian Anemia Pada Ibu Hamil di Puskesmas Karta Raharja dan Puskesmas Marga Kencana Kab. Tulang Bawang Barat Tahun 2020

\begin{tabular}{|c|c|c|c|c|c|c|}
\hline \multirow{2}{*}{ Variabel Independen } & \multicolumn{2}{|c|}{ Kejadian Anemia } & \multirow{2}{*}{$\begin{array}{c}N \\
(\%)\end{array}$} & \multirow{2}{*}{ Total } & \multirow{2}{*}{$\begin{array}{c}P \\
\text { value }\end{array}$} & \multirow{2}{*}{$\begin{array}{c}\text { POR } \\
\text { (Cl 95\%) }\end{array}$} \\
\hline & Anemia & Tdk Anemia & & & & \\
\hline Paritas & & & & & & \multirow{3}{*}{4,995} \\
\hline$\geq 4$ & 10 & 10 & 20 & \multirow{2}{*}{100} & \multirow{2}{*}{0,017} & \\
\hline$<4$ & 12 & 68 & 80 & & & \\
\hline Umur & & & & & & \\
\hline$<20$ atau $>35$ th & 10 & 10 & 20 & \multirow{2}{*}{100} & \multirow{2}{*}{0,017} & \multirow{2}{*}{3,918} \\
\hline $20-35$ th & 12 & 68 & 80 & & & \\
\hline Jarak kelahiran & & & & & & \\
\hline$<2$ th & 16 & 6 & 22 & \multirow{2}{*}{100} & \multirow{2}{*}{0,000} & \multirow{2}{*}{1,579} \\
\hline$\geq 2$ th & 6 & 72 & 78 & & & \\
\hline Status Gizi & & & & & & \\
\hline Kurang & 8 & 26 & 34 & \multirow{2}{*}{100} & \multirow{2}{*}{0,851} & \multirow{2}{*}{7,288} \\
\hline Baik & 14 & 52 & 66 & & & \\
\hline \multicolumn{7}{|l|}{ Infeksi dan Penyakit } \\
\hline Ada & - & - & - & \multirow{2}{*}{100} & \multirow{2}{*}{1,000} & \multirow[t]{2}{*}{ - } \\
\hline Tidak & 22 & 78 & 100 & & & \\
\hline
\end{tabular}




\begin{tabular}{lcccccc}
\hline Usia Kehamilan & & & & & & \\
TM I \& III & 8 & 40 & 20 & 100 & 0,382 & 2,420 \\
TM II & 14 & 38 & 80 & 0 & \\
\hline
\end{tabular}

Tabel 4.

Faktor Eksternal Terhadap Kejadian Anemia Pada Ibu Hamil di Puskesmas Karta Raharja dan Puskesmas Marga Kencana Kab. Tulang Bawang Barat Tahun 2020

\begin{tabular}{|c|c|c|c|c|c|c|}
\hline \multirow{2}{*}{ Variabel Independen } & \multicolumn{2}{|c|}{ Kejadian Anemia } & \multirow{2}{*}{$\begin{array}{c}N \\
(\%)\end{array}$} & \multirow{2}{*}{ Total } & \multirow{2}{*}{$\begin{array}{c}P \\
\text { value }\end{array}$} & \multirow{2}{*}{$\begin{array}{l}\text { POR } \\
\text { (Cl 95\%) }\end{array}$} \\
\hline & Anemia & Tdk Anemia & & & & \\
\hline \multicolumn{7}{|l|}{ Pendidikan } \\
\hline Rendah & 12 & 42 & 54 & \multirow{2}{*}{100} & \multirow{2}{*}{0,967} & \multirow{2}{*}{0,896} \\
\hline Tinggi & 10 & 36 & 46 & & & \\
\hline Pendapatan Keluarga & & & & & & \multirow[b]{2}{*}{5,037} \\
\hline $\begin{array}{l}\text { Rendah } \\
\text { Tinggi }\end{array}$ & $\begin{array}{l}16 \\
6\end{array}$ & $\begin{array}{l}60 \\
18\end{array}$ & $\begin{array}{l}76 \\
24\end{array}$ & 100 & 0,774 & \\
\hline Pekerjaan & & & & & & \\
\hline $\begin{array}{l}\uparrow S \text { Stress } \\
\neq \uparrow \text { Stress }\end{array}$ & $\begin{array}{c}4 \\
18\end{array}$ & $\begin{array}{l}10 \\
68\end{array}$ & $\begin{array}{l}14 \\
86\end{array}$ & 100 & 0,651 & 6,733 \\
\hline \multicolumn{7}{|l|}{ Konsumsi PMT \& Tablet Fe } \\
\hline $\begin{array}{l}\text { Kurang } \\
\text { Baik }\end{array}$ & $\begin{array}{c}0 \\
22\end{array}$ & $\begin{array}{c}0 \\
78\end{array}$ & $\begin{array}{c}0 \\
100\end{array}$ & 100 & 1,000 & - \\
\hline
\end{tabular}

Tabel 5.

Faktor Internal yang Paling Dominan Terhadap Kejadian Anemia Pada Ibu Hamil di Puskesmas Karta Raharja dan Puskesmas Marga Kencana Kab. Tulang Bawang Barat Tahun 2020

\begin{tabular}{lcccc}
\hline \multirow{2}{*}{$\begin{array}{c}\text { Variabel } \\
\text { Independen }\end{array}$} & \multicolumn{3}{c}{ Kejadian Anemia } \\
\cline { 2 - 5 } & P-Value & POR & \multicolumn{2}{c}{ 95\% Cl for Exp(B) } \\
\cline { 4 - 5 } & 0,017 & 4,995 & Lower & Upper \\
\hline Paritas & 0,017 & 3,918 & 0,000 & - \\
\hline Umur & 0,000 & 1,579 & 0,138 & 111,351 \\
\hline Jarak Kelahiran & & & 0,000 & - \\
\hline
\end{tabular}

Pada tabel 4 terlihat bahwa tidak ada variabel faktor eksternal yang berhubungan dengan kejadian Anemia pada ibu hamil

Pada tabel 5 dapat disimpulkan bahwa faktor internal yang paling berhubungan dengan kejadian Anemia pada ibu hamil adalah paritas ibu ( $P$ Value 0.017), umur ibu ( $P$ Value 0.017), dan jarak kelahiran (P Value 0.000).

\section{PEMBAHASAN}

Berdasarkan hasil penelitian dapat diketahui bahwa ibu hamil yang mengalami Anemia sebanyak $26 \%$ dari total responden yang ada di Puskesmas Kartaraharja dan Marga Kencana. Satus Gizi ibu hamil, $34 \%$ mengalami status gizi kurang dan $8 \%$ diantaranya mengalami anemia. Pada Penelitian ini, Usia kehamilan responden didominasi oleh responden trimester II sebanyak $56 \%$ dan $8 \%$ megalami anemia. Dan $22 \%$ ibu hamil yang mengalami anemia tidak memiliki penyakit infeksi.
Hasil uji statistik Tidak ada hubungan yang signifikan antara status gizi, usia kehamilan, infeksi dan penyakit dengan kejadian Anemia. Walaupun demikian, tetap harus diwaspadai untuk ketiga faktor tersebut. Kebutuhan zat besi pada wanita Hamil yaitu raa-rata mendekati $800 \mathrm{mg}$. Kebutuhan ini terdiri dari; sekitar $300 \mathrm{mg}$ dierlukan untuk janin dan plasenta, $500 \mathrm{mg}$ digunakan untuk meningkatkan masa haemoglobin maternal. Kurang lebih 200 mg akan diekskresikan lewat usus, urin, dan kulit. Sehingga makanan ibu hamil setiap 100 kalori akan menghasilkan \pm 8-10 $\mathrm{mg}$ zat besi. Perhitungan 3x makan dengan 2500 kalori baru menghasilkan 20-25 mg zat besi perhari. Jika di hitung selama kehamilan (288 hari), ibu hamil baru mendaptkan zat besi $100 \mathrm{mg}$ dari makanan yang ia makan, sehingga kebutuhan zat besi masih belum tercukupi jika tidak ditambah tablet zat besi (Royadi \& Manoe, 2010). Kebutuhan zat besi pada setiap kehamilan + $900 \mathrm{mg} \mathrm{Fe}$ untuk pembentukan sel 


\section{JKM (Jurnal Kebidanan Malahayati),Vol 7,No.3.Juli 2021, ISSN (Print) 2476-8944 ISSN (Online) 2579-762X, Hal 510-517}

darah ibu, plasenta dan darah janin (Manuaba, 2010).

Hasil penelitian ini menunjukkan, Dari 100 orang ibu hamil yang menjadi responden penelitian, dapat dilihat bahwa ibu hamil dengan paritas $\geq 4$ anak ada $10 \%$ ibu (10 orang) mengalami Anemia, hasil uji statistik didapatkan variabel yang paling berhubungan dengan kejadian Anemia pada ibu hamil adalah lbu yang melahirkan anak $\geq 4$ orang, beresiko 5 kali mengalami Anemia ( $\mathrm{Cl} 95 \%=4.995$ ) bila dibandingkan dengan ibu yang melahirkan anak kurang dari 4 . Ibu dengan paritas $>3$ mempunyai risiko 8-9 kali lebih tinggi untuk mengalami anemia dibandingkan ibu dengan paritas $<3$ (Irianti B, et al, 2015), Hal ini didukung juga dengan teori Wijianto (2002) dalam Hidayati \& Andyarini (2018), setelah kehamilan yang ketiga resiko anemia meningkat, hal ini disebabkan karena pada kehamilan yang berulang menimbulkan kerusakan pada pembuluh darah dan dinding uterus yang biasanya mempengaruhi sirkulasi nutrisi ke janin. Paritas atau jumlah persalinan juga berhubungan dengan anemia. Semakin sering seorang wanita melahirkan maka semakin besar resiko kehilangan darah dan berdampak pada penurunan kadar $\mathrm{Hb}$. Setiap kali wanita melahirkan, jumlah zat besi yang hilang diperkirakan sebesar $250 \mathrm{mg}$.

Pada penelitian ini juga didapat bahwa ibu hamil yang berumur rentan ( $<20$ atau $>35$ tahun) ada 10\% ibu (10 orang) mengalami Anemia, hasil uji statistik didapatkan variabel yang paling berhubungan dengan kejadian Anemia pada ibu hamil adalah usia lbu hamil dengan umur $<20$ atau $>35$ tahun beresiko 4 kali mengalami Anemia $(\mathrm{Cl}$ $95 \%=3.918$ ) jika dibandingkan dengan ibu hamil usia 20-35 tahun. SDKI (2012), menemukan tingginya mortalitas neonatal, bayi dan balita pada ibu dengan umur < 20 tahun daripada 20-39 tahun (Kemenkes, 2014). Usia seorang wanita pada saat hamil sebaiknya tidak terlalu muda dan tidak terlalu tua, umur yang kurang dari 20 tahun dan lebih dari 35 tahun beresiko tinggi untuk melahirkan (Depkes, 2014).

Defisiensi zat besi timbul pada saat kebutuhan akan zat besi meningkat, misalnya pada wanita usia reproduktif. Pada tingkat umur yang berbeda, terdapat varian kebutuhan zat besi setiap hari. Konsentrasi $\mathrm{Hb}$ yang rendah berhubungan dengan usia ibu yang akstrime (terlalu tua atau terlalu muda). Pada usia kurang dari 20 tahun kondisi masih dalam pertumbuhan, sehingga masukan makanan banyak dipakai untuk pertumbuhan ibu yang dapat mengakibatkan gangguan pertumbuhan janin (Lealem G., et. al, 2015). Sedangkan pada ibu hamil di atas usia 35 tahun cenderung mengalami anemia disebabkan karena pengaruh turunnya cadangan zat besi dalam tubuh. Pada kehamilan pertama pada wanita berusia di atas 35 tahun juga akan memunyai risiko penyulit persalinan dan mulai terjadinya penurunan fungsifungsi organ reproduksi (Demmouche $\mathrm{A}$, et. al, 2011).

Pada penelitian ini juga terlihat bahwa, ibu hamil yang memiliki jarak kelahiran $<2$ tahun ada $16 \%$ ibu (16 orang) mengalami Anemia, hasil uji statistik didapatkan variabel yang paling berhubungan dengan kejadian Anemia ibu hamil dengan jarak kelahiran $<2$ tahun lebih beresiko 2 kali mengalami Anemia jika dibandingkan dengan ibu hamil yang jarak kelahiran anaknya $>2$ tahun $(\mathrm{Cl}$ $95 \%=1.579$ ). Adanya hubungan antara jarak kehamilan dengan kejadian anemia salah satu penyebabnya adalah karena organ reproduksi ibu belum benar-benar pulih. Hasil penelitian ini sejalan dengan teori yang disampaikan oleh Prawirohardjo (2014) bahwa salah satu faktor yang menyebabkan anemia pada masa kehamilan dalan jarak kelahiran yang $<2$ tahun karena pemenuhan kebutuhan zat gizi belum optimal setelah memenuhi kebutuhan nutrisi janin yang dikandung. Hasil penelitian ini didukung oleh pendapat Nurhidayat yang menyatakan bahwa ibu hamil dengan jarak kehamilan yang terlalu dekat dapat meyebabkan anemia. Hal ini terjadi karena kondisi ibu yang belum terlalu pulih sehingga pemenuhan kebutuhan asupan zat gizi untuk tubuh ibu kurang optimal. Jika asupan gizi selama hamil tidak mencukupi maka dapat menyebabkan ibu hamil kekurangan energi kronik dan bisa menyebabkan ibu mengalami anemia (Gusnidarsih, 2020).

Untuk faktor eksternal, seperti faktor Pendidikan ibu, pendapatan keluarga, pekerjaan ibu hamil, dan Konsumsi PMT \& Tablet Fe. Hasil uji statistik pada faktor eksternal didapatkan tidak ada hubungan secara signifikan dengan kejadian anemia pada ibu hamil. Hal ini berbeda dari beberapa penelitian dikatakan bahwa pendapatan, Pendidikan, dan pekerjaan berhubungan dengan anemia pada kehamilan (Campigotto AC, et al, 2015). Hal tersebut berhubungan dengan pilihan makanan yang mengandung zat gizi. Makin tinggi tingkat pendapatan, Pendidikan, dan pekerjaan ibu hamil, maka makin besar kemungkinan ibu hamil untuk mendapatkan asupan gizi yang seimbang untuk kehamilannya. Meskipun secara statistik ketiga variabel ini tidak menunjukkan hubungan yang bermakna, namun hal ini tentu saja berimbas pada tingginya prevalensi anemia. WHO dalam penelitian acak dibeberapa negara mengatakan bahwa, intervensi penting dapat diberikan kepada 
ibu hamil selama 4 kali kunjungan pada waktu tertentu. Hal tersebut dilakukan untuk mencegah anemia dan menangani anemia secara dini (Amanupunnyo, et al, 2018). Selain itu, Ibu Hamil di wilayah puskesmas Karta Raharja \& Marga Kencana patuh dalam mengkonsumsi PMT \& Tablet Fe yang diberikan secara berkala oleh pihak puskesmas melalui Kader maupun Bidan Desa. Sehingga dapat menekan angka kejadian kehamilan beresiko di Wilayah tersebut.

\section{SIMPULAN}

Faktor Internal yaitu Paritas ibu ( $p$-value= 0.017), umur ibu ( $p$-value $=0.017)$, dan jarak kelahiran $(p$-value $=0.000)$ merupakan Faktor internal yang paling berhubungan dengan kejadian Anemia pada ibu hamil di Puskesmas Karta Raharja \& Marga Kencana Kab. TUBABA.

Faktor eksternal didapatkan tidak ada hubungan secara signifikan dengan kejadian anemia pada ibu hamil di Puskesmas Karta Raharja \& Marga Kencana Kab. TUBABA.

\section{SARAN}

Pentingnya pendidikan kesehatan pada Ibu hamil atau sebelum terjadi kehamilan untuk merubah perilaku ibu hamil sehingga dapat hidup sehat dan menjadi wadah pengetahuan yang menjadikan ibu memiliki kemampuan yang baik dan benar begitu pula sebaliknya. Hasil penelitian ini dapat terus ditingkatkan untuk memberikan informasi dan referensi pembelajaran yang lebih relevan mengenai determinan Anemia sebagai salah satu upaya pencegahan dan mendukung tercapainya Kesehatan Ibu di Tulang Bawang Barat.

\section{DAFTAR PUSTAKA}

Adisasmito. (2017). Gizi dalam Daur Kehidupan. Penerbit Buku Kedokteran EGC. Jakarta : EGC.

Amalia, (2017). Pengantar Pendidikan Kesehatan dan IImu Prilaku. Jakarta, Rineka Cipta

Amanupunnyo, NA., Shaluhiyah, Z., \& Margawati A., (2018). Analisis Faktor Penyebab Anemia Pada Ibu Hamil di Puskesmas Kairatu Seram Barat. Jurnal Aisyah: Jurnal IImu Kesehatan, 3(2), Desember 2018, - 174. https://ejournal.stikesaisyah.ac.id/index.php/ji $\mathrm{kal}$

Ariyani, Rizqi, \& Sarbini, Dwi., (2016). Faktor-Faktor Yang Mempengaruhi Kejadian Anemia Pada Ibu Hamil Trimester III Di Wilayah Kerja Puskesmas Mojolaban, Kabupaten Sukoharjo. Skripsi thesis, Universitas
Muhammadiyah Surakarta. Diakses Dari : http://eprints.ums.ac.id/42421/

Barat, D. K. (2017). Profil Dinas Kesehatan Kabupaten Tulang Bawang Barat. Tulang Bawang Barat: Dinas Kesehatan Provinsi.

Cakrawati, D., (2012). Bahan Pangan, Gizi dan Kesehatan. Bandung: Alfabeta.

Campigotto AC, De Farias M do C, AD.,, Pinto FDC, Albuquerque FFG. (2015). Factors Relating to Iron Deficiency Anemia in Pregnancy: An Integrative Review. Int Arch Med.1215

Demmouche A, Khelil S, \& Moulessehoul S. (2011). Anemia Among Pregnant Women in the Sidi Bel Abbes Region (West Algeria). Journal of Blood Disorders and Transfusion 2:113.

Depkes RI. (2014). Studi Tindak lanjut Ibu Hamil. Hal $57-67$

Gusnidarsih, Vevi., (2020). Hubungan Usia dan Jarak Kehamilan Dengan Kejadian Anemia Klinis Selama Kehamilan. Jurnal Asuhan lbu \& Anak, JAIA Vol: 5, No. 1, Februari 2020 https://doi.org/10.33867/jaia.v5i1.155

Gedefaw, L., Ayele, A., Asres, Y., \& Mossie, A. (2015). Anemia and Associated Factors Among Pregnant Women Attending Antenatal Care Clinic in Wolayita Sodo Town, Southern Ethiopia. Ethiopian journal of health sciences, 25(2), 155-62. http://dx.doi.org/10.4314/ejhs.v25i2.8

Umu Hani, L. R. (2018). Gambaran Umur dan Paritas pada Kejadian KEK. Yogyakarta: Universitas Aisyiyah (UNISA) .

Hidayati \& Andyarini., (2018). Hubungan Jumlah Paritas dan Umur Kehamilan dengan Kejadian Anemia Ibu Hamil Journal of Health Science and Prevention, Vol.2(1), April 2018 ISSN 2549-919X (online)

Indonesia, D. K. (2017). Badan Penelitian dan Pengembangan Kesehatan Departemen Kesehatan Republik Indonesia. Jakarta: Depkes RI.

Irianti, Bayu. et al., (2015). Asuhan Kehamilan Berbasis Bukti. Paradigma Baru Dalam Asuhan Kebidanan. Buku 1. Husin Farid, editor. Jakarta: Sagung Seto.

Kementerian Kesehatan Republik Indonesia. (2014). Infodatin : Situasi Kesehatan Reproduksi Remaja. Diakses : https://pusdatin.kemkes.go.id/folder/view/01/ structure-publikasi-pusdatin-info-datin.html

Lampung, D. K. (2017). Profil Dinas Kesehatan Provinsi Lampung. Lampung: Dinkes Provinsi Lampung.

Lealem G. et al. (2015). Anemia and Associated Factors Among Pregnant Women Atteding 
JKM (Jurnal Kebidanan Malahayati),Vol 7,No.3.Juli 2021,

ISSN (Print) 2476-8944 ISSN (Online) 2579-762X, Hal 510-517

Antenatal Care Clinic in Wolayita Sodo Town, Southern Ethiopia. Ethiop J Health Sci. Vol 25. No 2. 2015

Litbangkes, B. (2018). Riset Kesehatan Dasar (Riskesdas). Jakarta: Kemenkes RI.

Manuaba, dkk., (2010). Ilmu Kebidanan Penyakit Kandungan dan Keluarga Berencana Edisi 2. Jakarta, EGC.

Nurhidayah, (2013). Hubungan Antara Pengetahuan, Sikap, Dan Tindakan Ibu Hamil Tentang Nutrisi Dengan Kejadian Anemia Selama Kehamilan Di Puskesmas Sudiang Makassar. Jurnal IImiah Kesehatan, vol. 3, no. 4, p. 90-99, nov. 2013. ISSN 2302-1721

Prawirohardjo S, (2014). IImu Kebidanan. Edisi ke5. Jakarta: PT Bina Pustaka Sarwono Prawirohardjo.

Proverawati A. (2011). Anemia dan Anemia Kehamilan. Yogyakarta: Nuha Medika.

Royadi \& Manoe, (2010). Anemia dalam Kehamilan. Departemen Obstetri dan Ginekologi Fakultas Kedokteran UnHas. Diakses dari : https://med.unhas.ac.id/obgin/?p=102
Saifuddin AB., (2011). Panduan Praktis Pelayanan Kesehatan Maternal dan Neonatal. Jakarta : EGC.

Sjahriani, T., \& Faridah V., (2019). Faktor-Faktor Yang Berhubungan Dengan Kejadian Anemia Pada Ibu Hamil. Jurnal Kebidanan Volume 5, Nomor 2, April 2019. ISSN 2579$762 X$

Sulistioningsih, (2015). Kejadian Anemia Pada Kadar Hemoglobin. Jakarta : EGC.

Yanuarti Petrika, H. H. (2016). Tingkat asupan energi dan ketersediaan pangan berhubungan dengan risiko kekurangan energi kronik (KEK) pada ibu hamil. Jurnal Gizi dan Dietetik Indonesia (Indonesian Journal of Nutrition and Dietetics), http://dx.doi.org/10.21927/ijnd.2014.2(3).140-149.

Yuliatin, (2018). Kehamilan. Jilid I. Buku Kedokteran. Jakarta : EGC.

Zahidatul Rizkah, T. M. (2017). Hubungan Antara Umur, Gravida, Dan Status Bekerja Terhadap Resiko Kurang Energi Kronis (KEK) Dan Anemia Pada Ibu Hamil. Surabaya: Universitas Airlangga. 